Chicago-Kent College of Law

Scholarly Commons @ IIT Chicago-Kent College of Law

January 2011

\title{
The Gendered Lives of Legal Aid: Lay Lawyers, Social Workers, and the Bar, 1863-1960
}

Felice J. Batlan

IIT Chicago-Kent College of Law, fbatlan@kentlaw.iit.edu

Follow this and additional works at: https://scholarship.kentlaw.iit.edu/fac_schol

Part of the Law and Gender Commons, Law and Society Commons, and the Legal History Commons

\section{Recommended Citation}

Felice J. Batlan, The Gendered Lives of Legal Aid: Lay Lawyers, Social Workers, and the Bar, 1863-1960, (2011).

Available at: https://scholarship.kentlaw.iit.edu/fac_schol/72

This Article is brought to you for free and open access by the Faculty Scholarship at Scholarly Commons @ IIT Chicago-Kent College of Law. It has been accepted for inclusion in All Faculty Scholarship by an authorized administrator of Scholarly Commons @ IIT Chicago-Kent College of Law. For more information, please contact jwenger@kentlaw.iit.edu, ebarney@kentlaw.iit.edu. 


\section{Working Manuscript}

The Gendered Lives of Legal Aid: Lay Lawyers, Social Workers, and the Bar, 1863-1960 (working title)

\section{Felice Batlan}

Significantly challenging what we believe to be the history of legal aid, this work will demonstrates that organized free legal aid for the poor grew out of women's work. In fact, in the mid-to-late nineteenth century, the provision of legal aid in New York City, Chicago, and Philadelphia, though developing in different configurations and in a variety of historical circumstances, involved the creation of legal aid for women and this aid was provided primarily by elite and middle-class women who were not lawyers. I call these women lay lawyers. The day-to-day work of these organizations, including interviewing clients, providing legal advice, investigating cases, and negotiating settlements was carried out by women at a time when many law schools and state bars excluded women. In these first generation legal aid organizations a male attorney became involved only when a case went to court -- a rare occurrence. These organizations specialized in poor women's claims against employers and husbands and understood women primarily as vulnerable victims who were prey to men's schemes, appetites, and undisciplined behavior in the marketplace and the home. As depicted by such organizations, these helpless virtuous victims, without the power of legal aid, faced death from starvation or prostitution.

By the turn of the century, as women in small numbers began graduating from law schools, some joined the then just developing second generation legal aid societies as fullfledged attorneys. These second generation legal aid societies represented and provided advice to both men and women. Yet as was the case with first-generation legal aid societies, women's claims against employers and husbands continued to saturate the record. Indeed, the prevailing 
image of the legal aid client was a poor working woman who had a wage claim against an employer, or an abused or abandoned wife in need of a divorce or maintenance. It is fair to say that from the 1860 s through the early 1900 s, legal aid was deeply feminized in terms of legal aid providers, legal aid clients, and how legal aid represented itself to the public. This, however, would not remain the case.

As male legal aid lawyers came to the fore in the first decade of the twentieth century, they sought to create a national association of legal aid societies. Other goals included expanding legal aid societies across the country, standardizing the provision of legal aid services, widely publicizing the importance of legal aid, and gaining the support of bar associations. In the process, women's visibility as clients, lay lawyers, and even professional lawyers declined. The image of the legal aid client also changed from a poor woman to a poor man with a wage claim. Indeed the poor man was not entitled to legal aid by virtue of his vulnerability but rather as a means to reestablish his manly independence.

While these transformations were occurring, social work began emerging as a profession and women lay lawyers were now considered social workers. At least some leaders of legal aid, the most famous being Reginald Heber Smith, firmly believed that social workers had little or no role in providing legal aid. These leaders aimed to align legal aid with bar associations while thoroughly professionalizing and masculinizing it. This process involved re-writing the history of legal aid to render women as lay lawyers and clients invisible. This exclusion from history was not unintentional. Rather it served a variety of purposes including depicting legal aid as the brainchild of male attorneys and presenting the substantive work of legal aid as conducted and controlled by male lawyers. As this occurred, some legal aid societies began to curtail the services that they provided to women. Legal aid thus fits into the much larger pattern of men 
professionalizing women's work and then excluding women. Such men were not motivated by animus but rather the practice of law was so associated with men that the female bastion of legal aid did not look like a real legal practice but rather like charity.

For example, Reginald Heber Smith's foundational and still canonical Justice and the Poor (1919), provided the first extended discussion of the history of legal aid, and was part of a larger project to court bar associations and to disassociate legal aid from philanthropy and the developing field of social work which were closely associated with women. In Justice and the Poor, Smith wrote, "The most important thing about the Boston Legal Aid Society is the fact that its initial impulse came entirely from the bar .... The scope of the work is confined to the field of legal action ... It is a distinct thing from charity work, it requires the legally trained mind acting in the light of a knowledge of legal affairs."1

We must understand Smith to be reflecting the common understanding that charity enshrined types of dependence. Smith instead positioned legal aid as a method of creating the independent male citizen. Indeed as many clients of legal aid were immigrants, legal aid became a lesson in male citizenship. Moreover, Smith absolutely believed that lawyers who attended law school (especially elite law schools), possessed unique skills and training which substantially differed from that of the professionally trained or untrained social worker. He further hoped that aligning legal aid with bar associations would convince bar associations and lawyers to financially support legal aid. Justice and the Poor was embraced by many of the new male leaders of legal aid and essentially became a bible, long providing legal aid with a reformulated history and blueprint for the future. Later scholars and writers examining legal aid often have cited and used Smith's

\footnotetext{
${ }^{1}$ Reginald Heber Smith, Justice and the Poor: A Study of the Present denial of Justice to the Poor and the Agencies Making more Equal their Position before the Law, with Particular Reference to Legal Aid Work in the United States (New York: Carnegie Foundation, 1919), 141, 178.
} 
work as an accurate account of the history of legal aid - so much so that few have questioned it and it is now enshrined.

This project of masculinizing legal aid never was complete and at times was deeply contested. Throughout the 1920 s and 1930 s, social workers asserted their own authority over the provision of legal aid, especially with the development of specialized courts, such as juvenile and domestic courts, often staffed by female social workers and lay lawyers. As my work will show, many social workers and their allies believed that legal aid clients were entitled to much broader services than those provided by legal aid societies dominated by attorneys. By the early 1920 s, when four out of five social workers were women, the leaders of legal aid exhibited a full-fledged panic over legal aid's relationship to social work and this panic mapped onto issues of gender, authority, expertise, and professionalization.

This heated controversy raised issues such as the nature of the role of lawyers, what it meant to practice law, whether law was a specialized form of knowledge, whether legal training should be reserved for lawyers, what services legal aid should provide, the proper role and training of social workers, and what clients' legal aid should serve. Although scholars of legal aid have long pointed to legal aid societies' conservative nature, social workers and their hard-hitting critiques of legal aid and of law in general presented an alternative and potentially more radical version of legal aid which was based on wide-ranging ideas of social justice.

The Gendered Life of Legal Aid, 1863-1960 will be the first monograph on the history of civil legal aid in the United States. By closely examining the history of legal aid in New York, Chicago, and Boston, it presents a number of arguments with wide-ranging implications and it is animated by a host of conflicts. These include what justice means, the relationship between legal aid and citizenship, the changing status of domestic relations law, the interactions between 
lawyers and social workers and their different understandings of the role and nature of law, and even how the history of legal aid should be told. More specifically the work questions what it historically meant to "practice law" or "to be a lawyer" and argues that women practiced law before they were admitted to law school in large numbers or could be admitted to state bars. Thus it puts in historical context and collapses the categorical dichotomy of lawyer versus nonlawyer and argues that our understanding of women practicing law in the nineteenth century needs to account for women lay lawyers. It also demonstrates that the practice of law from the nineteenth century through the first decades of the twentieth century was more democratic, heterogeneous, and less elite than we currently appreciate. 